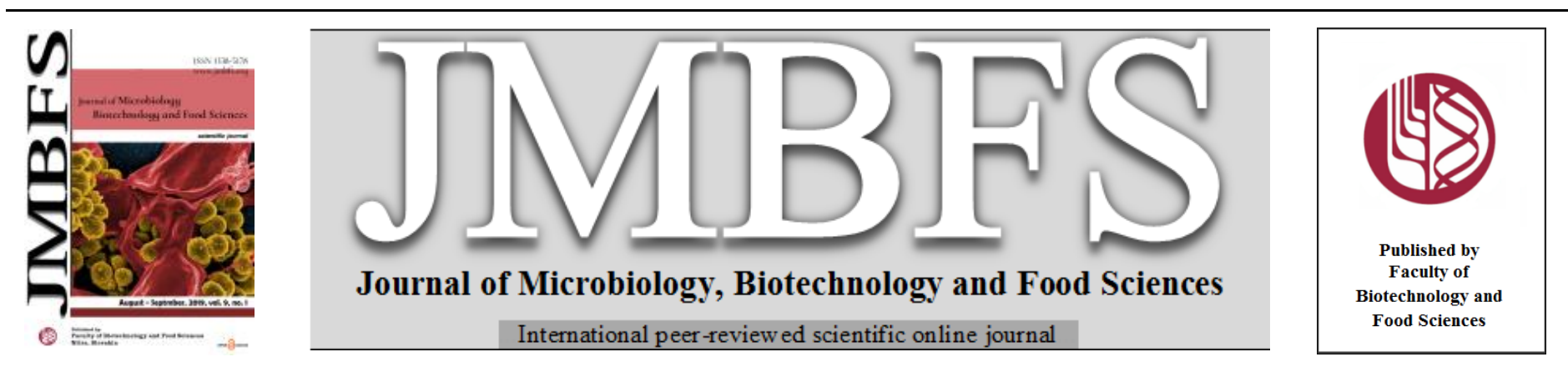

\title{
INTEGRATED DISEASE MANAGEMENT OF BULL'S EYE PATHOGEN INFECTING LYCOPERSICON ESCULENTUM (TOMATO)
}

\section{Deepti Sadana, Nidhi Didwania}

Address(es): Nidhi Didwania

Department of Biotechnology, Faculty of Engineering and Technology, Manav Rachna International Institute of Research and studies, Haryana, (INDIA) -121004.

*Corresponding author: nidhididwania77@gmail.com

doi: 10.15414/jmbfs.2019.9.1.53-57

\section{ARTICLE INFO}

Received 22. 2. 2018

Revised 13.3. 2019

Accepted 13. 3. 2019

Published 1. 8. 2019

Regular article OPEN $\partial_{\text {AcCESS }}$

\begin{abstract}
Early blight disease in Lycopersicon esculentum (Tomato) caused by Alternaria solani is a disease posing economical threat to tomato cultivation worldwide. The efficacy of fifteen plant extracts (Polyalthia longifolia, Azadirachta indica, Datura stramonium, Ocimum sanctum, Calotropis procera, Crotalaria juncea, Eucalyptus obliqua, Cassia fistula Agele marmelos, Croton bonplonadium, Pergularia daemia, Cleome viscose, Phyllanthus amarus, Bauhinia purpurea and Euphorbia hirta), five Trichoderma harzianum strains $\left(\mathrm{T}_{1}, \mathrm{~T}_{2}, \mathrm{~T}_{3}\right.$, $\mathrm{T}_{4}$ and $\mathrm{T}_{5}$ ) and seven de oiled cakes (neem cake, castor cake, karanj cake, mustard cake, groundnut cake, salmeal cake and mahua cake) were investigated in vitro and in vivo conditions. In laboratory conditions, all the treatments inhibited the mycelium of A. solani. $\mathrm{T}_{5}$ strain of Trichoderma harzianum (81\%), Eucalyptus obliqua (80.7\% at $15 \%$ concentration) among plant extracts and karanj cake (48.6\% at $10 \%$ concentration) among de oiled cakes recorded maximum mycelium inhibition of the pathogen. Pot culture experiments were further conducted to check the combined effect of selected plant extracts and de oiled cakes (from laboratory conditions) with Trichoderma harzianum. All the three compatible constituents were further evaluated in the field conditions. The combination of $\mathrm{T}_{5}+$ Eucalyptus obliqua + karanj cake recorded maximum inhibition of $(59.8 \%)$ against $A$. solani and was comparable with fungicide mancozeb (71.8\%). Foliar spray application of tomato plants with all the combined constituents has significantly reduced the early blight infection as compared to untreated control. Thus, it could be concluded that the synergistic effect of combined constituents may be an efficacious treatment against Alternaria solani as an invulnerable option to synthetic agrochemicals.
\end{abstract}

\section{INTRODUCTION}

Early blight disease of tomato is caused by Alternaria solani has consistently been one of the utmost constraints in the tomato production. It causes tomato yield losses from 35 to $78 \%$ (Basu, 1971; Datar \& Mayee, 1981). Imprudent use of synthetic agrochemicals for managing plant diseases has crucial negative effects on humans and agro ecosystem. Eco friendly reign measures together with extracts of botanicals and organic constituents act directly or indirectly on phytopathogens by inducing systemic resistance in plants. Natural products have attained considerable deliberation as substitute means to synthetic agrochemicals. Attempts have been made to manage plant diseases using plant extracts, bio control agents and de oiled cakes separately (Ramachandran, 2006; Kakavan, 2013 and Shabana, 2016). Their utilization in the biological procedures offers privilege in bio detoxification and biological remediation of hazardous constituents. The plant extracts are efficacious natural agents against a broad range of phytopathogens viz. bacteria, fungus, virus and nematodes. Plants contain secondary metabolites viz. phenols, flavonoids, tannins and coumarins that are toxic and also called natural bio pesticides (Irshad et al., 2011). These constituents serve for the systemic defense mechanisms against plant pathogens. The benign effects of Trichoderma harzianum is that it has the potentiality to establish the symbiotic relationships with the plant by enhancing plants growth, development and productivity aiding to overcome biotic and abiotic stresses and boosting nutrient absorption (Harman et al., 2006). Trichoderma species are multitasking activist that have multiple mechanism potentialities viz. antibiosis, inactivation of enzymes in pathogen, hyper parasitism and competition for space with pathogens (Thangavelu

et al., 2004).

The de oiled cakes are the residues left after the extraction of oil from the seeds of the plants. They serve as exemplary substratum for the growth and development of microorganisms by providing the necessary nutrients to them and thus, indirectly serving to boost up the systemic resistance in plants (Kumari $\boldsymbol{e}$ al., 2013). Their application in the farmer's field is beneficial as it suppresses disease and improves plant health by increasing nutrients in soil. (Bagwan 2010 Bruggen et al. 2016).

The compatibility of Trichoderma harzianum with botanical extracts and de oiled cakes respectively in aggregation has verified its capabilities against several plant pathogens (Tapwal et al., 2012; Sadana et al. 2015; Singh et al. 2015; Tomer et al., 2016). Not much work has been done on the research of compatibility of the three constituent's collectively. The synergistic effect of bio control agents with plant extracts and de oiled cakes altogether is an combined integrated disease management approach for management of blight disease which has the efficiency to increase the plant growth. Hence, in the present investigation evaluation of Trichoderma harzianum strains in combination with both plant extracts and de oiled cakes was undertaken to determine their effects on early blight disease in green house conditions.

\section{MATERIAL AND METHODS}

\section{Media cultures and microorganisms}

Entire cultures in the research investigation were procured from Hi media chemicals, India. Healthy seeds of tomato plants were achieved from Indian Agriculture Research Institute (IARI), Pusa, New Delhi. The strains of antagonist viz. Trichoderma harzianum and pathogen Alternaria solani were isolated from the diverse host plants from various fields of Faridabad.

\section{Preparation of botanicals}

The fifteen botanical plant materials viz. Eucalyptus obliqua, Polyalthia longifolia, Azadirachta indica, Datura stramonium, Ocimum sanctum, Calotropis procera, Crotalaria juncea, Cassia fistula, Agele marmelos, Croton bonplonadium, Pergularia daemia, Cleome viscose, Phyllanthus amarus, Bauhinia purpurea, Euphorbia hirta were selected on the basis of antimicrobial properties. The plant material was collected from the fields of national centre for integrated Pest management (NCIPM), Faridabad. It was surface sterilized with 
$0.1 \%$ sodium hypochlorite $(\mathrm{NaOCl})$ and washed four to five times with distilled water, dried in oven for 48 hours at $50-60^{\circ} \mathrm{C}$ and then exquisitely grinded to powder. Magnificent plant powders were preserved separately (Mehrotra, 2003).

\section{Preparation of de oiled cake}

Seven de oiled cakes viz. neem cake, castor cake, karanj cake, mustard cake, groundnut cake, salmeal cake and mahua cake were selected on the basis of their efficacies to increase the longevity of Trichoderma harzianum in previous studies. (Sumbul and Singh, 2015). All the de oiled cakes were sterilized and crushed to crude powder with the help of heavy pestle and mortar separately. The powder was further used for the evaluation in the laboratory conditions against $A$. solani.

Evaluation of various strains of Trichoderma harzianum, plant powders and de oiled cakes against Alternaria solani in vitro conditions

The antagonistic efficacy of five strains of Trichoderma harzianum viz, $\mathrm{T}_{1}, \mathrm{~T}_{2} \mathrm{~T}_{3}$, $\mathrm{T}_{4}$ and $\mathrm{T}_{5}$ against Alternaria solani was determined by the dual culture technique on Potato dextrose agar medium in laboratory conditions (Dalpati, 2010). The petriplates were incubated at room temperature of $28 \pm 2{ }^{\circ} \mathrm{C}$. The observation of the mycelial growth of Alternaria solani was estimated after five days of inoculation. The laboratory experiments were accomplished twice.

Evaluation of fifteen plants and seven de oiled cakes was determined by poison food technique at different concentrations against $A$. solani.

The percent inhibition was calculated and the data was analyzed statistically (Vincent, 1947).

Percent Inhibition $=$ Control - Treated $/$ Control $\times 100$

where, Control is the colony diameter of $A$. solani in Petri plates and Treated is the colony diameter of $A$. solani in Petriplates grown with Trichoderma strains.

The two maximum inhibiting strains of Trichoderma harzianum, plant leaf powders and de oiled cakes was selected for pot culture studies.

Evaluation of selected treatments against Alternaria solani on tomato in green house studies

For the seed investigation, tomato seeds of Sinnovo Lyco variety were surface sterilized with $1 \%$ sodium hypochlorite. Then they were rinsed with sterile water thrice and transferred to $20 \mathrm{~cm}$ diameter petri dishes containing treatment respectively. For the experiment, 60 seeds of tomato plants were selected (15 seeds for each green house pots). Surface wet seeds of tomato plants were rolled in $2 \mathrm{gm}$ of treatment for 10 minutes in petri plates respectively till completely coated.

Developed treatments were determined for their efficacy in controlling early blight disease of tomato in green house conditions conducted in complete randomized design with nine treatments (eight combinations and an untreated control) each with three replications. Each replicate constituted of mud pot containing $5 \mathrm{Kg}$ of pre-inoculated pasteurized field soil with A. solani inoculums at the rate of one percent $(\mathrm{w} / \mathrm{w})$ and 15 tomato seeds coated with each treatmen separately. The culture of $A$. solani was prepared by multiplying it on autoclaved potato dextrose broth for a week in the incubator at $28 \pm 2^{\circ} \mathrm{C}$. It was dried, blended out and utilized as inoculums in the green house studies as described prior.

Pots were placed with $12 \mathrm{~h}$ light photo period conditions in green house experiments and watered as per requirement. The survived tomato seedlings were enumerated in each pot after 60 days of sowing. The efficiency of treatments in controlling early blight disease was then evaluated by the comparison of survived number of tomato seedlings in distinct combinations with untreated control. The experiment was implemented twice.

Evaluation of selected treatments against Alternaria solani on tomato in field conditions

The magnificent combinations from the pot experiments were further evaluated in the field conditions against $A$. solani. The research studies in the field experiment were conducted by RBD (randomized block design) with replications. The sowing of tomato was performed on $10 \mathrm{~m} \times 15 \mathrm{~m}$ plots, spacing involved $90 \mathrm{~cm} \times 60 \mathrm{~cm}$. Tomato plants were inoculated with the A. solani $(2000 \mathrm{ml}$ inoculums) suspension with atomizers. The efficacy of selected combinations was determined in controlling early blight disease, germination percent, seedling length and vigor index. Germination percentage was determined by the method suggested by Arancon (2012) with the given formulae:

$\mathrm{GP}=$ Germinated seeds /Total seeds $\mathrm{x} 100$

Vigor index of the tomato plant was estimated by the method proposed by Abdul- Baki and Anderson (1973) according to the formulae: VI (Vigor index) $=$ seedling height $\mathrm{x}$ seed percentage; Seedling height $=$ Mean of root length + Mean of shoot length $(\mathrm{cm})$

\section{Statistical analysis}

Statistical analysis was carried out for the laboratory and green house experiments using SPSS software. Data for the different treatments of healthy seedlings at distinct time intervals were subjected to ANOVA (analysis of variance). The levels of significance were then determined. Comparison was determined with LSD (Least significant difference) at $\mathrm{p} \leq 0.05$.

\section{RESULTS AND DISCUSSION}

Evaluation of various strains of Trichoderma harzianum against Alternaria solani in vitro conditions

All the five isolates of Trichoderma harzianum significantly inhibited the growth of $A$. solani (Fig 1). Among them $\mathrm{T}_{5}$ isolate $(81 \mathrm{~mm})$ exhibited the maximum efficacy in inhibition of $A$. solani mycelium growth followed by $\mathrm{T}_{1}(76.6 \%)$. Minimum percent inhibition against $A$. solani was observed in $\mathrm{T}_{4}$ isolate $(64.3 \%)$. The comprehensive results of this study depicts that Trichoderma strains have significant antagonistic effects on $A$. solani, a pathogenic fungus causing blight disease on tomato plant. In previous investigations, the inhibitory influence of metabolites (volatile and non-volatile) of Trichoderma harzianum on pathogens were exhibited in vitro and vivo conditions which is in conformity with the results of present study. Results of metabolites viz. chitinase enzyme produced by T. harzianum, T. flavus and T. asperellum showed their efficiency in controlling diseases caused by various plant pathogens (Thangavelu et al., 2004; Kakvan et al. 2013).

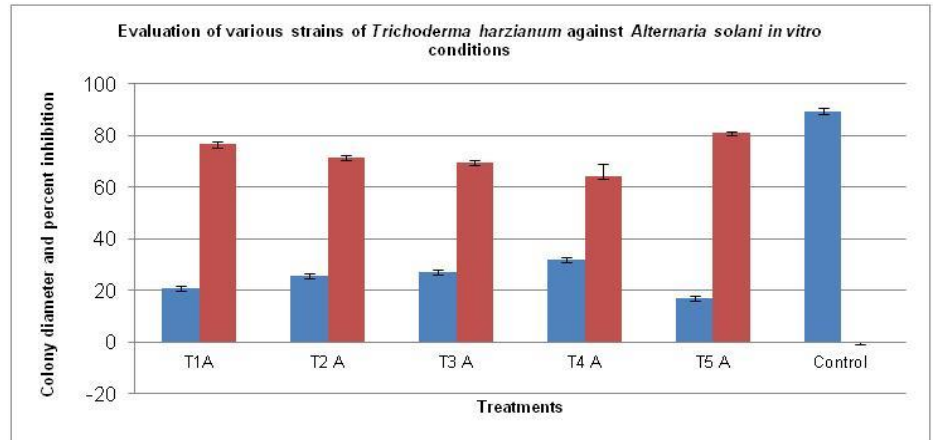

Figure 1 Evaluation of various strains of Trichoderma harzianum agains Alternaria solani in vitro conditions

Trichoderma isolates are the auspicious biocontrol agents that has antifungal potentialities against phytopathogens (Patale and Mukadam, 2010; Gomathy and Ambikapathy, 2011). The antibiosis, antagonistic and competition mechanisms against plant pathogens make Trichoderma species a versatile activist that offers multi task benefits to the farmers. The study is in conformity with Singh and Kumar (2011), Jat and Agalave (2013) who evaluated the cultural characteristics and bio control potential of Trichoderma strains isolated locally from the fields and found it to be highly efficient against pathogens

Evaluation of various plant extracts against Alternaria solani in vitro conditions

In vitro, all the fifteen plant extracts significantly inhibited the mycelium of $A$ solani. The ultimate plant extract was observed to be Eucalyptus obliqua $(80.7 \%)$ followed by Calotropis procera (74\%) and Azadirachta Indica (73.6\%). Minimum inhibition was observed in Cleome viscose (35\%) (Fig 2). The study is in conformity with the studies of Sallam et al. (2011) who studied the effect of six plant extracts viz., sweet basil, neem, eucalyptus, oleander, jimson weed and garlic and found the highest reduction caused by jimson weed, garlic and neem. Similar studies were undertaken by Sharma and Trivedi (2002) on plant leaf extracts and observed the best results of Calotropis procera and Datura stramonium against $F$. oxysporum. Plant extracts are the effective agents to synthesize secondary metabolites viz. phenols, quinines, flavones, tannins etc that are effective against various pathogens (Tapwal et al. 2011; Nashwa et al. 2012). Similar studies were undertaken by Ganie et al. (2013) investigated the bioefficacy of five plant extracts and found Datura stramonium to be superior exhibiting mycelium inhibition of $A$. solani. 
Evaluation of various plant extracts against Alternaria solani in vitro conditions

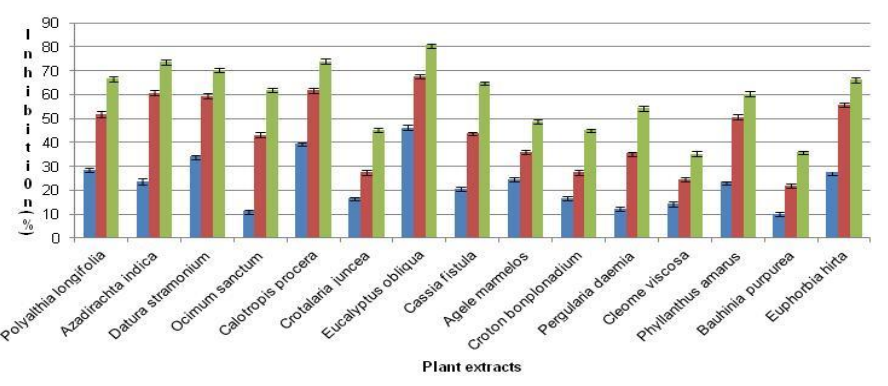

Figure 2 Evaluation of various plant extracts against Alternaria solani in vitro conditions

Evaluation of various de oiled cakes against Alternaria solani in vitro conditions

The entire de oiled cakes evaluated inhibited A. solani pathogen in the laboratory conditions. The percent inhibition in karanj cake $(48.6 \%)$ was found to be maximum at $10 \%$ concentration against $A$. solani followed by mahua cake $(40.4 \%)$ and mustard cake $(28.8 \%)$ (Fig 3). Inhibition was found to be maximum in karanj cake $(43.7 \%)$ at $15 \%$ concentration followed by neem $(39.9 \%)$ and mustard cake $(36.7 \%)$ at $15 \%$ concentration. Minimum percentage was observed in salmeal cake $(5.9 \%)$. The study is in conformity

with Singh et al. (2015) who stated in his works that the implementation of de oiled cakes alleviate the field fertility status and supplements by minimizing disease occurrence risk factors. The de oiled cakes has the bio pesticides efficiency and add plant

growth promoter factors to the crop (Tomer et al., 2015)

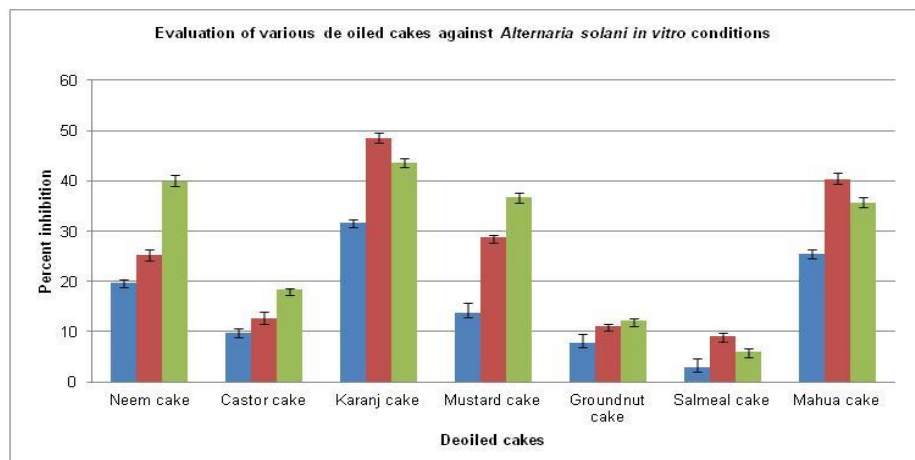

Figure 3: Evaluation of various de oiled cakes against Alternaria solani in vitro conditions

Evaluation of Trichoderma harzianum in combination with plant extracts and de oiled cakes at different concentrations against $A$. solani on tomato in green house studies

In the above mentioned in vitro experiments $\mathrm{T}_{5}$, Eucalyptus obliqua and karanj cake were found to be the ultimate constituents to design the bio formulation. The Green house experiments were conducted to evaluate the compatibility of selected isolates of $T$. harzianum with botanicals and de oiled cakes. The results affirmed that the maximum inhibition was observed in the combination of $\mathrm{T}_{5}+E$ obliqua $(48.7 \%)$ at $15 \%$ concentration followed by $\mathrm{T}_{2}+$ E. obliqua $(43.2 \%)$ and in the combination of de oiled cakes the combination of $\mathrm{T}_{5}+$ Karanj cake $(37.9 \%)$ at $10 \%$ concentration followed by the combination of $\mathrm{T}_{2}+$ karanj cake $(22.5 \%)$. The minimum inhibition of $A$. solani was observed in the combinations of $\mathrm{T}_{2}+C$. procera $(29.1 \%)$ at $15 \%$ concentration and $\mathrm{T}_{2}+$ neem cake $(14.7 \%)$ (Table 1$)$. In the present investigation maximum percent inhibition was observed by the combinations of $\mathrm{T}_{5}$, Eucalyptus obliqua and karanj cake.

Tapwal (2012) during his investigations observed that botanicals are compatible with isolates of Trichoderma spp. to inhibit the soil borne phytopathogens. The research work is in conformity with several pathologists (Bheemaraya, et al. 2012; Maheshwari et al., 2014) who stated that the botanical extracts of plants viz. Eucalyptus, Azadirachta seed kernel, Allium cepa, Allium sativum and Pongamia pinnata in combination with Trichoderma strains were inhibitory to plant pathogens. In an integrated pest management package synergistic effect of various combinations of natural products contribute solution to the environmental and human health hazards caused by synthetic agrochemicals. Plant leaf extracts of Adiantum, Urtica and Parthenium were compatible to Trichoderma and found inhibitory against $A$. zinnia, $A$. solani, $R$. solani, $C$. lunata and $F$. oxysporum (Tapwal 2011). Similar investigations were undertaken by Tomer et al. (2015) who demonstrated that the combined application of bio-control agents on de oiled cakes viz. neem and jatropha results in increase of root length (3 times), shoot length (1.5 times) and fruit yield (5 times) increase in yields of tomato fruit crop.

Table 1 Evaluation of Trichoderma harzianum in combination with plant extracts and de oiled cakes at different concentrations against $A$. solani on tomato in green house studies

\begin{tabular}{|c|c|c|c|c|c|c|}
\hline \multirow[t]{2}{*}{ Treatments } & \multicolumn{3}{|c|}{$\begin{array}{c}\text { Disease severity (DS } \\
\%)\end{array}$} & \multirow[b]{2}{*}{$5 \%$} & \multicolumn{2}{|c|}{$\begin{array}{c}\text { Percent Inhibition } \\
(\text { PI \%) } \\
\end{array}$} \\
\hline & $5 \%$ & $10 \%$ & $15 \%$ & & $10 \%$ & $15 \%$ \\
\hline $\mathrm{T}_{5}+$ E. obliqua & 63.2 & 42.1 & 37.3 & 15.5 & 42.0 & 48.7 \\
\hline $\mathrm{T}_{5}+$ C. procera & 57.4 & 51.2 & 47.2 & 23.2 & 29.4 & 35.1 \\
\hline $\mathrm{T}_{5}+$ Karanj cake & 53.4 & 48.1 & 45.2 & 28.6 & 33.7 & 37.9 \\
\hline $\mathrm{T}_{5}+$ Neem cake & 68.3 & 64.2 & 59.2 & 8.69 & 11.5 & 18.6 \\
\hline $\mathrm{T}_{2}+$ E. obliqua & 64.0 & 48.3 & 41.3 & 14.4 & 33.4 & 43.2 \\
\hline $\mathrm{T}_{2}+C$. procera & 62.3 & 57.6 & 51.6 & 16.7 & 20.6 & 29.1 \\
\hline $\mathrm{T}_{2}+$ Karanj cake & 66.1 & 60.1 & 56.4 & 11.6 & 17.2 & 22.5 \\
\hline $\mathrm{T}_{2}+$ Neem cake & 70.9 & 64.2 & 62.1 & 5.2 & 11.5 & 14.7 \\
\hline Control & 74.8 & 72.6 & 72.8 & 0 & 0 & 0 \\
\hline $\mathrm{SE} \pm(\mathrm{m})$ & 0.85 & 0.83 & 0.94 & 0.55 & 0.80 & 0.78 \\
\hline $\mathrm{SE} \pm(\mathrm{d})$ & 1.21 & 1.18 & 1.33 & 0.78 & 1.14 & 1.10 \\
\hline CD $1 \%$ & 2.56 & 2.50 & 2.81 & 1.66 & 2.42 & 2.33 \\
\hline
\end{tabular}

*Average of three replications, $\mathrm{T}_{5}\left(2 \times 10^{7}\right)$ spores/ml, Plant extracts $(15 \%$ concentration), de oiled cakes ( $10 \%$ concentration)

Results of the above mentioned investigations conclude that the compatibility of the Trichoderma harzianum with plant extracts and de oiled cakes is a prerequisite for management of early blight disease and increase in crop productivity.

\section{Evaluation of bio formulations against Alternaria solani in field conditions}

The selected combination of Trichoderma harzianum strains with plant extracts and Trichoderma harzianum strains with de oiled cakes in the pot culture studies were further evaluated to determine the compatible combinations of Trichoderma harzianum strains, plant extracts and de oiled cakes altogether. All the eight treatments enhanced the number of survived tomato seedlings significantly and were able to reduce the blight disease incidence as compared to untreated control. The utmost efficient combination was observed to be $\mathrm{T}_{5}+$ E. obliqua + karan cake (59.8 Percent inhibition) followed by $\mathrm{T}_{2}+E$. obliqua + karanj cake $(52.4$ Percent inhibition) blight disease incidence and $\mathrm{T}_{5}+$ E. obliqua + neem cake (47.2 Percent inhibition) (Table 2). Results exhibit the significant enhancement in germination percentage against Alternaria solani in combined treatment of $\mathrm{T}_{5}+$ E. obliqua + karanj cake $(86.3 \%)$ to be the maximum with 1242.7 vigor index and minimum in $\mathrm{T}_{2}+C$. procera + neem cake $(52.0 \%)$ with 505.9 vigor index. The significant increase in root length (7.24) and shoot length (7.16) was observed on application of the above mentioned combination of $\mathrm{T}_{5}+$ E. obliqua + karanj cake when compared to all the other combined treatments. The maximum blight incidence was observed in control (72.8). The untreated control of tomato seedling had the lowest vigor index (233.4).

In the previous studies several pathologists have evaluated bio control agents, plant extracts and de oiled cakes separately but not much work has been done on the combined synergistic effect of the three constituents together. The comprehensive results of this research work indicates that combination of $T$ harzianum, E. obliqua and karanj cake have remarkable effects on $A$. solani, a soil borne pathogenic fungus causing early blight disease on tomato. Development and formation of Integrated disease management powder form is a vital factor in practical implement of Trichoderma harzianum because it can aid the farmers for the easy application as seed treatment for managing early blight disease particularly seed borne pathogens under field conditions. The study is in conformity with several workers that Trichoderma harzianum plays a significant role in managing the soil borne phytopathogens and give quality response in enhancing the major parameters of plants viz. germination percent, seedling length and vigor index (Afroz, 2008; Patel, 2014; Yucel, 2017). 
Table 2 Evaluation of selected combinations of treatments against Alternaria solani in field conditions

\begin{tabular}{|c|c|c|c|c|c|c|c|}
\hline Treatments & $\mathrm{G} \%$ & $\mathrm{RL}(\mathrm{cm})$ & $\mathrm{SL}(\mathrm{cm})$ & $\begin{array}{l}\text { SEL } \\
(\mathrm{cm})\end{array}$ & VI & $\mathrm{DS} \%$ & PI\% \\
\hline $\mathrm{T}_{2}+$ E. obliqua + Karanj cake & 82.1 & 6.98 & 6.78 & 13.76 & 1129.6 & 34.6 & 52.4 \\
\hline $\mathrm{T}_{2}+$ C. procera + Karanj cake & 65.0 & 4.89 & 5.62 & 10.15 & 659.75 & 57.2 & 21.4 \\
\hline $\mathrm{T}_{2}+$ E. obliqua + Neem cake & 66.0 & 4.76 & 5.04 & 9.80 & 646.8 & 51.2 & 29.6 \\
\hline $\mathrm{T}_{2}+C$. procera + Neem cake & 52.0 & 4.25 & 5.48 & 9.73 & 505.9 & 61.3 & 15.8 \\
\hline $\mathrm{T}_{5}+$ E. obliqua + Karanj cake & 86.3 & 7.24 & 7.16 & 14.4 & 1242.7 & 29.2 & 59.8 \\
\hline $\mathrm{T}_{5}+$ C. procera + Karanj cake & 71.6 & 5.82 & 5.52 & 11.3 & 809.08 & 43.6 & 40.1 \\
\hline $\mathrm{T}_{5}+$ E. obliqua + Neem cake & 78.2 & 6.94 & 5.91 & 12.8 & 1000.9 & 38.4 & 47.2 \\
\hline $\mathrm{T}_{5}+C$. procera + Neem cake & 68.0 & 5.50 & 6.23 & 11.73 & 797.64 & 48.6 & 33.2 \\
\hline Mancozeb & 87.4 & 7.82 & 7.51 & 15.3 & 1339.8 & 19.4 & 71.8 \\
\hline Control & 38.2 & 2.65 & 3.46 & 6.11 & 233.4 & 72.8 & 0 \\
\hline $\mathrm{SE} \pm(\mathrm{m})$ & 0.68 & 0.33 & 0.48 & 0.47 & 14.14 & 0.92 & 0.76 \\
\hline $\mathrm{SE} \pm(\mathrm{d})$ & 0.96 & 0.47 & 0.68 & 0.67 & 14.88 & 1.31 & 1.08 \\
\hline CD $5 \%$ & 2.046 & 1.005 & 1.443 & 1.428 & 28.517 & 2.72 & 2.21 \\
\hline
\end{tabular}

*G\% (Germination \%), RL (Root length) (cm), SL (Shoot length) (cm), SEL (Seedling length), VI (vigor index), DS (Disease severity \%), PI (Percent inhibition \%); ${ }_{5}$ $\left(2 \times 10^{7}\right)$ spores/ml, Plant extracts $(15 \%$ concentration), de oiled cakes (10\% concentration), mancozeb $(0.2 \%)$

\section{CONCLUSIONS}

The present investigations may have practical implementation in the integrated pest management strategies in which reduction of agrochemicals, increase in yield and protection of environmental bio resources are of major concerns. Since both tomato and blight disease are vital in the world, it is concluded based on the comprehensive results that the development of Trichoderma bio formulation with Eucalyptus obliqua and karanj cake may be potentially effectual method in managing Alternaria solani causing early blight disease of tomato.

\section{REFERENCES}

Abdul-Baki, A. and Anderson, J.D. (1973). Vigor determination in Soybean seed by multiple criteria. Crop Sci., 13,630-633. https://doi.org/10.2135/cropsci1973.0011183x001300060013x

Afroz M., Ashrafuzzaman M., Ahmed M. N., Ali M. E. and Azim M. R. (2008). Integrated Management of Major Fungal Diseases of Tomato. Int. J. Sustain. Crop Prod. 3(2):54-59.

Arancon, N.Q., Pant, A., Radovich, T., Hue, N.V., Potter, J. K. and Converse, C.E. (2012). Seed Germination and Seedling Growth of Tomato and Lettuce as affected by vermicompost Water Extracts (Teas), HortScience, 47 (12):17221728 https://doi.org/10.21273/hortsci.47.12.1722

Bagwan, N.B. (2010). Evaluation of Trichoderma compatibility with fungicides, pesticides, organic cakes and botanicals for integrated management of soil borne diseases of soybean (Glycine max (L) Merrill). Int. J. Plant Prot, 3, 206-209.

Basu, P.K. (1971). Existence of chlamydospores of Alternaria porri. f. sp. solan as over wintering propagules in soil. Phytopathology, 61, 1347-1350 https://doi.org/10.1094/phyto-61-1347

Bheemaraya, Patil, M.B., Ramesh, Vendan, K.T., Amaresh, Y.S. and Rao, K. (2012). Compatibility of Trichoderma spp. with commonly used fungicides, insecticides and plant extracts. Indian Journal of Plant Protection 40(2), 118 122.

Bruggen, A.H.C. V., Finckh M.R. (2016). Plant Diseases and Management Approaches in Organic Farming Systems. Annual Review of Phytopathology, 54 (1), 25-54. https://doi.org/10.1146/annurev-phyto-080615-100123

Dalpati, N.N.S., Parate, R.L., Ingle, S.T. (2010). Efficacy of some bio agents and botanicals against Alternaria macrospora causing leaf spot of cotton. Journal of plant diseasesciences, 5 , (1), 95-97

Datar, V.V., Mayee, C.D. (1981). Assessment of loss in tomato yield due to early blight. Indian Phytopathology, 34, 191-195.

Ganie, S.A., Ghani, M.Y., Anjum, Q., Nissar, Q., Rehman, S.U., Dar, W.A (2013). Integrated management of early blight of potato under Kashmir valley conditions. Academic journals, 32 (8), 4318-4325.

Gomathy, S., Ambikapathy, V. (2011). Antagonistic activity of fungi against Pythium debaryanum (Hesse) isolated from chilli fields soil. J. Advances in ap Sci. Res., 2(4) 4, 291- 297.

Harman, G.E. (2006). Overview of mechanisms and uses of Trichoderma spp.',Phytopathology, 96, 190-194. https://doi.org/10.1094/phyto-96-0190

Irshad, S., Butt, M. Youns, H. (2011). In-vitro antibacterial activity of two medicinal plants; neem (Azadirachta indica) and peppermint Int J Pharm, 1, 914.

Jat, J.G. and Agalave, H.R. (2013). Antagonistic properties of Trichoderma species against oilseed -borne fungi. Science Research Reporter, vol. 3, no.2, pp.171-174.

Kakvan, N., Heydari, A., Zamanizadeh, H.R., Rezaee, S., and Naraghi L. (2013). Development of new bio formulations using Trichoderma and
Talaromyces fungal antagonists for biological control of sugar beet damping-off disease. Crop Prot,53(0),80-84. https://doi.org/10.1016/j.cropro.2013.06.009 Kumari, A., Kumar, R., Maurya, S. Choudhary, J.S. and Kumar, S. (2013) Antifungal efficacy of aqueous extracts of neem cake, karanj cake and vermicompost against some phytopathogenic fungi. The Bioscan, 8, 671-674. Maheshwari, M. (2014). Compatibility study of isolates of Trichoderma spp. with plant extracts. Asian J. Bio. Sci. 9(2), 242 245.https://doi.org/10.15740/has/ajbs/9.2/242-245

Mehrotra R.S. and Aggarwal A. 2003. Plant Pathology. Tata McGraw-Hill (P) Ltd., New Delhi. pp. 815-824

Mishra, S.K. and Raja, R. (1999). Systemic acquired resistance: a review. Ann Agric Res, 20, 249-259.

Nashwa, S.M.A. and Abo- Elyousr, K.A.M. (2012). Evaluation of various plant extracts against the early bight disease of tomato plants under green house and field conditions. Plant protect. Sci. vol.48, pp.74 -79.

Patale, S.S. and Mukadam, D.S. (2011). Management of plant pathogenic fungi by using Trichoderma species. Bioscience Discovery, 2, (1), 36-37.

Patel, R. and Patel, D. (2014). Screening of Trichoderma and antagonistic analysis of a potential strain of Trichoderma for production of a bioformulation. International Journal of Scientific and Research Publications. 4 (10), 2250-3153. Ramachandran, S., Singh, S.K., Larroche, C., Soccol, C.R. and Pandey, A (2007). Oil cakes and their biotechnological applications - A review, 98 (10) 2000-2009. https://doi.org/10.1016/i.biortech.2006.08.002

Sadana, D. and Didwania, N. (2015). Bioefficacy of fungicides and plant extracts against Alternaria solani causing early blight of tomato. Inernational conference on plant, Marine and environmental conference Jan, 1-2, Kuala Lumpur,Malaysia. https://doi.org/10.15242/iicbe.c0115072

Sallam, N.M.A. (2011). Control of tomato early blight disease by certain aqueous plant -extracts, Plant pathol. J., 10, pp, 187-191. https://doi.org/10.3923/ppj.2011.187.191

Shabana, Y.M., Abdalla, M.E., Shahin, A.A., El-sawy, M.M., Draz, I.S and Youssif, A.W. (2016). Efficacy of plants extracts in controlling wheat leaf rust disease caused by Puccinia triticina. Egyptian journal of Basic and Applied Science, 4, 67-73.https://doi.org/10.1016/j.ejbas.2016.09.002

Sharma, N. and Trivedi, P. C. (2002). Screening of leaf of some extracts of plants for their nematicidal and fungicidal properties against Meloidogyne incognita and Fusarium oxysporum. Asian J. Exp. Sci. 16, 1\&2, pp, 21-28.

Singh, A., Shahid, M., Pandey, N.K., Kumar, S., Srivastava, M. and Biswas, S.K. (2011). Influence of temperature, $\mathrm{pH}$ and media for growth and sporulation of Trichoderma atroviride and its Shelf life study in different carrier based formulation. J Pl Dis Sci, 6: 32-34

Singh, P.K. and Kumar, V. (2011). Cultural characteristics and bio control potential of locally isolated Trichoderma harzianum', Bioscience Discovery., 2 (2), 67-70.

Singh, R., Kumar, A. and Tomer, A. (2015). De-oiled Cakes of Neem, Jatropha, Mahua and Karanja: A New Substrate for Mass Multiplication of T. harzianum. J Plant Pathol Microb 6:288. https://doi.org/10.4172/2157-7471.1000288

Sumbul, A., Rizvi, R., Mahmood, I. and Ansari, R. A. (2015). Oil-Cake Amendments: Useful Tools for the Management of Phytonematodes. Asian $\begin{array}{llll}\text { Journal of Plant } & \text { 9athology, 91-111. }\end{array}$ https://doi.org/10.3923/ajppaj.2015.91.111

Tapwal, A., Kumar, R., Gautam, N. and Pandey, S. (2012). Compatibility of Trichoderma viride for Selected Fungicides and Botanicals. International Journal of Plant Pathology, 3: 89-94. https://doi.org/10.3923/ijpp.2012.89.94 Tapwal, A, Nisha, Garg, S and Kumar, R 2011, 'In vitro Antifungal potency of plant extracts against five phytopathogens', Brazilian archives of 
biology and Technology, vol. 54, pp. 1093-1098. https://doi.org/10.1590/s1516$\underline{89132011000600003}$

Thangavelu, R., Palaniswami, A. and Velazhahan, R. (2004). Mass production of Trichoderma harzianum for managing Fusarium wilt of banana. Agriculture https://doi.org/10.1016/j.agee.2003.09.026

Tomer, A., Singh, R. and Maurya, M. (2015). Determination of compatibility of Pseudomonas fluorescens and Trichoderma harizianum grown on de oiled cakes of neem and jatropha for mass multiplication of $P$. flourescens and Trichoderma harzianum in vitro. African Journal of Agricultural Research, 10 (2), 67-75. https://doi.org/10.5897/ajar2014.8874

Tomer, A., Singh, R. and Singh, P. (2016). Suitability of de-oiled cakes of neem, jatropha, mahua and karanj along with cereals and millets substrates for mass multiplication of Trichoderma harzianum. Academy of Agriculture Journal, 1, 23-27. https://doi.org/10.4172/2157-7471.1000288

Vincent, J.M. (1947). Distortion of fungal hyphae in presence of certain
inhibitors.
Nature,
150
850

https://doi.org/10.1038/159850b0

Yücel, S., Karaçanc1, S. and Ay, T. (2017). Activity and bioformulation of Trichoderma harzianum for management of tomato diseases caused by soilborne pathogens. Acta

Hortic. 1164,339-344

https://doi.org/10.17660/actahortic.2017.1164.43 